\title{
Analisis Kondisi Hidrologi DAS Siak Bagian Hulu berdasarkan Peta Tata Guna Lahan Tahun 2014 Menggunakan Model Flow Persistance
}

\author{
Habrio Ilva ${ }^{1}$, Imam Suprayogi ${ }^{2 *}$, Manyuk Fauzi ${ }^{3}$ \\ 1,2,3 Program Magister Teknik Sipil Bidang Konsentrasi Hidroteknik Fakultas Teknik Universitas Riau, Pekanbaru 28293 \\ Universitas Riau, Kampus Bina Widya Jl. HR. Soebrantas KM 12,5 Pekanbaru, Kode Pos 28293 \\ E-mail : habrioilva900@gmail.com,imam@unri .ac.id, manyuk.fauzi@unri .ac.id
}

\begin{abstract}
ABSTRAK
Daerah Aliran Sungai (DAS) memiliki fungsi yang sangat penting, yaitu sebagai tempat penyedia air pertanian, industri dan pemukiman. Aktivitas manusia dalam memanfaatkan sumber daya alam hutan, tanah dan air untuk budidaya tanaman, pertambangan, pembangunan dan kegiatan lainnya dapat mengakibatkan terjadi perubahan kondisi tata air suatu DAS. Salah satu cara untuk menilai kondisi DAS adalah dengan menggunakan model hidrologi. Tujuan utama penelitian adalah ini adalah menguji kemampuan suatu model untuk melakukan penilaian terhadap kondisi hidrologi DAS Siak bagian Hulu. Metode pendekatan yang digunakan dalam penelitian ini adalah Flow Persistance Model. Model ini mensimulasikan aliran sungai pada suatu DAS yang dikembangkan oleh World Agroforestry Centre (ICRAF) untuk membantu menilai kondisi suatu DAS. Data curah hujan yang digunakan dari Stasiun Petapahan Baru dari tahun 2006-2016, data AWLR stasiun Pantai Cermin yang mendiskripsikan pola hubungan tinggi muka air terhadap fungsi waktu bersumber dari BWS Sumatera III. Peta Tata guna lahan diperoleh dari BP - DASHL Indragiri Rokan untuk tahun 2014. Hasil utama penelitian membuktikan bahwa nilai FP sebesar 0.754 mengindikasikan bahwa nilai debit pada Sungai Siak yang relatip stabil selama kurun waktu penggunaan tata guna lahan pada DAS Siak Hulu tahun 2014 dengan klasifikasi fungsi DAS kondisi baik.
\end{abstract}

Kata kunci : DAS, Tata Guna Lahan, Debit Sungai, Model Flow Persistance

\section{ABSTRACT}

Watershed (DAS) has a very important function, namely as a provider of agricultural, industrial and residential water. Human activities in utilizing the natural resources of forests, land and water for crop cultivation, mining, development and other activities can result in changes in the water conditions of a watershed. One way to assess watershed conditions is to use a hydrological model. The main objective of this research is to test the ability of a model to conduct an assessment of the hydrological conditions of the Upper Siak watershed. This model simulates a river flow in a watershed developed by the World Agroforestry Center (ICRAF) to help assess the condition of a watershed. Rainfall data used from Petapahan Baru Station from 2006-2016, AWLR data from Pantai Cermin Station which describes the pattern of the relationship of water level to the time function sourced from BWS III Sumatera. Land use maps were obtained from BP - DASHL Indragiri Rokan for 2014. The main results of the study prove that the FP value of 0.754 indicates that the discharge value in the Siak River is relatively stable during the period of land use use in the Siak Hulu watershed in 2014 with the classification of watershed functions in good condition.Keywords: Watershed, Land Use, River Discharge, Flow Persistance Model

\section{PENDAHULUAN}

Daerah Aliran Sungai (DAS) memiliki fungsi yang sangat penting, yaitu sebagai tempat penyedia air pertanian, industri dan pemukiman. Dipertegas oleh Permenhut No: P.60 / Menhut-II / 2014 bahwa DAS berfungsi dalam memelihara keseimbangan ekologis yaitu sebagai sistem penunjang kehidupan. DAS juga merupakan ekosistem yang di dalamnya terjadi proses biofisik hidrologis yang dapat terjadi secara alamiah. Proses biofisik hidrologis DAS merupakan bagian dari siklus hidrologis, sedangkan kegiatan sosial ekonomi dan budaya masyarakat dilakukan untuk meningkatkan kesejahteraannya merupakan bentuk intervensi manusia terhadap sistem alami DAS.

Dikatakan oleh Asdak (2006), bila fungsi dari suatu DAS terganggu, maka sistem hidrologis akan 
terganggu. DAS sebagai tempat jatuhnya hujan, resapan dan penyimpanan air menjadi terganggu sehingga rusaknya sistem aliran sungai. Keadaan ini menyebabkan melimpahnya air di musim hujan dan kurangnya air di musim kemarau, hal ini akan menyebabkan perbedaan yang tajam antara debit sungai pada saat musim hujan dan kemarau yang merupakan indikator rusaknya suatu DAS. Masih menurut Asdak, (2006) aktivitas manusia dalam memanfaatkan sumber daya alam hutan, tanah dan air untuk budidaya tanaman, pertambangan, pembangunan dan kegiatan lainnya dapat mengakibatkan terjadi perubahan kondisi tata air suatu DAS ataupun pada ukuran lebih kecil seperti sub DAS atau sub-sub DAS.

Dipertegas oleh Tanika (2014) menjaga dan memperbaiki fungsi hidrologi suatu di DAS menjadi perhatian pamangku kepentingan daerah, khususnya pemerintah setempat. Untuk itu adanya alat dan indikator yang dapat digunakan untuk menilai baik tidaknya fungsi hidrologi suatu DAS sangatlah penting. Salah satu cara untuk menilai kondisi DAS adalah dengan menggunakan model hidrologi. suatu model hidrologi yang merupakan tiruan suatu sistem hidrologi menjadi sangat kompleks karena terdapat banyak komponen dan proses yang terlibat.

Selanjutnya Tanika (2014) menegaskan kembali bahwa model yang selanjutnya dinamakan Flow Persistence (FP) yang dikembangkan oleh Mane Van Noodrwijk dkk, dapat memberikan gambaran secara cepat mengenai kondisi DAS berdasarkan pola data debit harian. Model ini diharapkan dapat membantu pemangku kepentingan, terutama mereka yang tinggal dibagian hilir, dalam melakukan pemantauan terhadap kondisi hidrologi wilayah. Didukung penelitian yang telah dilakukan oleh Tanika pada tahun 2014 dengan menerapkan penggunaan model hidrologi Flow Persistance (FP) di DAS Besay Kecamatan Sumber Jaya, Kabupaten Lampung Barat Provinsi Lampung untuk mengukur indikator baik tidaknya fungsi hidrologi suatu DAS. Model Flow Persistence dapat memberikan diskripsi mengenai kondisi DAS berdasarkan pola data debit harian yang diperoleh dari Stasiun Automatic Water Level Record (AWLR). Model ini didasarkan pada autokorelasi antara debit hari ini dengan hari berikutnya. Menghitung nilai FP yang menunjukan kecenderungan atau perilaku debit sungai, dimana untuk nilai Fp sama dengan 0 yang mencirikan bahwa debit sungai sangat tidak beraturan sedangkan nilai Fp sama dengan 1 yang mengindikasikan bahwa debit sungai sangat stabil.
Merujuk keberhasilan penerapan Flow Persistance dalam mensimulasikan kondisi hidrologi pada Sub DAS Way Besai Kecamatan Sumber Jaya Kabupaten Lampung Barat Provinsi Lampung tersebut, maka penulis melakukan penelitian terkait penerapan model Flow Persistance tersebut untuk diaplikasikan pada DAS Siak Bagian Hulu di Provinsi Riau yang diklasifikan DAS kritis akibat perubahan penggunaan lahan / tutupan lahan yang cukup signifikan selama periode waktu 20 tahun terakhir pasca era reformasi tahun 1998.

\section{LANDASAN PUSTAKA}

\section{Konsep Model Flow Persistence}

Model Flow Persistance memberikan null-model yang didasarkan pada auto korelasi temporal atau Flow Persistence empiris dalam data aliran sungai. Pada penelitian ini metode yang digunakan untuk menghitung adalah hubungan rekursif antara aliran sungai $Q$ pada hari-hari berikutnya:

$$
\mathrm{Q}_{\mathrm{t}+1}=\mathrm{F}_{\mathrm{p}} \mathrm{Q}_{\mathrm{t}}+\mathrm{Q}_{\text {add }}
$$

Dengan $\mathrm{Q}_{\mathrm{t}}$ dan $\mathrm{Q}_{\mathrm{t}+1}$ adalah aliran sungai pada hari ke $\mathrm{t}$ dan aliran sungai pada hari ke $\mathrm{t}+1, \mathrm{~F}_{\mathrm{p}}$ adalah aliran faktor persistensi $\left(0<\mathrm{F}_{\mathrm{p}}<1\right)$ dan $\mathrm{Q}_{\mathrm{add}}$ adalah varian acak yang mencerminkan penambahan inputdari curah hujan.

Merujuk persamaan 1 di atas, membuktikan bahwa nilai varian acak yang mencerminkan penambahan input dari curah hujan $\left(\mathrm{Q}_{\mathrm{add}}\right)$ dan aliran faktor persistensi $(\mathrm{Fp})$ yang memiliki rentang antara 0 sampai $1\left(0<\mathrm{F}_{\mathrm{p}}<1\right)$ saling berhubungan. Jika $\mathrm{F}_{\mathrm{P}}$ memiliki nilai 1 dan $\mathrm{Q}_{\text {add }}$ memiliki nilai 0 maka persamaan 1 akan berubah menjadi persamaan 2 sebagai berikut :

$$
\mathrm{Q}_{\mathrm{t}+1}=\mathrm{Q}_{\mathrm{t}}
$$

Masih merujuk persamaan 2 di atas, maka dapat dikatakan bahwa debit sungai pada saat ini (Qt) akan sama nilainya dengan debit untuk satu hari ke depan $(\mathrm{Qt}+1)$ atau dengan kata lain nilai debit sungai relatif konstan.

$$
\begin{array}{cc}
\mathrm{FP}=\left(\mathrm{Q}_{\mathrm{t}+1}-\mathrm{Q}_{\mathrm{add}}\right) / \mathrm{Q}_{\mathrm{t}} \\
\mathrm{Q}=\mathrm{Q}_{\mathrm{s}}+\mathrm{Q}_{i}+\mathrm{Q}_{\mathrm{b}} \\
\mathrm{FPQ}=\mathrm{FP}_{\mathrm{S}} \mathrm{Q}_{\mathrm{s}}+\mathrm{FP}_{\mathrm{i}} \mathrm{Q}_{\mathrm{i}}+\mathrm{FPb}_{\mathrm{b}} \\
(5) \quad \\
\mathrm{FPQ}=\mathrm{FP}_{\mathrm{S}} \mathrm{Q}_{\mathrm{s}}+\mathrm{FP}_{\mathrm{i}} \mathrm{Q}_{\mathrm{i}}+\mathrm{Qb}
\end{array}
$$

\section{(6)}

Dimana $\mathrm{FP}_{\mathrm{S}} \mathrm{FP}_{\mathbf{i}}, \quad \mathrm{FPb}_{\mathrm{b}}$ merupakan nilai Flow Persistance pada aliran permukaan, aliran cepat dan aliran lambat.Karena aliran lambat memiliki sifat yang cenderung lambat dan stabil maka $\mathrm{FP}_{\mathrm{b}}$ mendekati 1 
sehingga Persamaan 5 menjadi Persamaan 6 sedangkan aliran permukaan dari aliran cepat bergantung pada curah hujan maka $\mathrm{FP}_{\mathrm{S}}$ dan $\mathrm{FP}_{\mathrm{i}}$ dapat diwakili oleh nilai ketahanan curah hujan (rain persistence atau RP).Gabungan antara persamaan 3, 4 dan 5 berubah menjadi Persamaan 7 sebagai berikut

$$
\mathrm{FP}=\mathrm{RP}(\mathrm{Q}-\mathrm{Qb}) / \mathrm{Q}+\mathrm{Qb} / \mathrm{Q}
$$

Jika input yang tersedia untuk model Flow Persistance hanya berupa nilai debit makaperhitungan nilai FP hanya menggunakan Persamaan 3 maka Nilai FP dihitung dengan menggunakan membuat grafik scatter plot antaraQt dan $\mathrm{Q}_{\mathrm{t}+1}$.

\section{METODE PENELITIAN}

Metode penelitian disusun berdasarkan latar belakang penelitian, identifikasi masalah, perumusan masalah serta tujuan utama dari penelitian.

\section{Lokasi Penelitian}

DAS Siak terletak di Provinsi Riau dengan luas wilayah 1.481.499,25 ha. Secara geografis wilayah DAS Siak berada pada posisi antara $100^{\circ} 28^{\prime}$ BT $102^{0} 12^{\prime}$ BT dan $0^{0} 20^{\prime}$ LU $-1^{0} 16^{\prime}$ LU. Secara administrasi terletak di Kabupaten Rokan Hulu, Kabupaten Kampar, Kabupaten Bengkalis, Kota Pekanbaru dan Kabupaten Siak. DAS Siak terdiri dari empat Sub DAS yaitu Sub DAS Tapung Kanan, Sub DAS Tapung Kiri, Sub DAS Mandau dan Sub DAS Siak Hilir. Khusus untuk penelitan ini hanya untuk DAS Siak Bagian Hulu yaitu Sub DAS Tapung Kanan, Sub DAS Tapung Kiri. Peta DAS Siak Bagian Hulu selanjutnya disajikan seperti pada Gambar 1 di bawah ini.

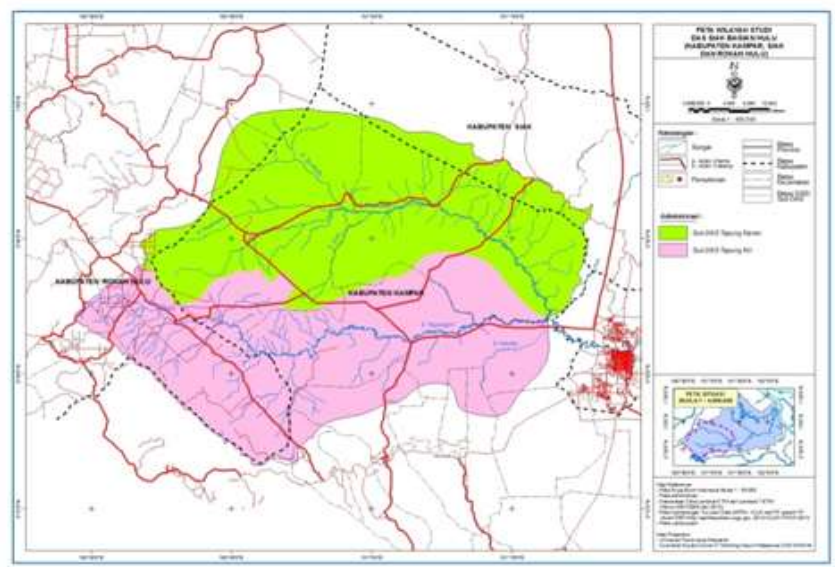

Gambar 1. Peta DAS Siak Bagian Hulu Sumber : Riyawan (2014)

\section{Pengumpulan Data}

Pengumpulan data penelitian adalah sebagai berikut :

1. Data curah hujan yang digunakan dari Stasiun Petapahan Baru dari tahun 2006-2016 yang bersumber dari Balai Wilayah Sungai (BWS) III Sumatera.

2. Data AWLR stasiun Pantai Cermin yang mendiskripsikan pola hubungan tinggi muka air terhadap fungsi waktu bersumber dari Balai Wilayah Sungai (BWS) III Sumatera.

3. Peta Tata guna lahan diperoleh dari BP DASHL Indragiri Rokan untuk tahun 2014

\section{Tahap Penelitian}

Tahapan-tahapan penelitian adalah sebagai berikut

1. Penyiapan data curah hujan dan data debit sebagai input data untuk Model Flow Persistance.

2. Model Flow Persistance secara otomatis akan melakukan analisis debit yang mendiskripsikan pola hubungan nilai debit pada saat $t \quad\left(Q_{t}\right)$ dan nilai debit pada saat $t+1\left(Q_{t+1}\right)$ menggunakan Persamaan dasar dari Model Flow Persistance yang mengikuti persamaan $\mathrm{Q}_{\mathrm{t}+1}=\mathrm{FP} \mathrm{Q}_{\mathrm{t}}+\mathrm{Q}_{\text {add. }}$

3. Penetapan nilai hasil persamaan Linier adalah $\mathrm{Q}_{\mathrm{t}+1}=\mathrm{AQ}_{\mathrm{t}}+\mathrm{B}$ dari Model Flow Persistance yang mendiskripsikan pola Grafik Hubungan antara $Q_{t}$ dan $Q_{t+1}$.

4. Penyusunan Grafik Hidrograf yang mendiskripsikan pola hubungan antara debit aliran sebagai fungsi waktu.

5. Menampilkan nilai FlowPer untuk empat periode untuk periode I yaitu pada awal musim hujan (Oktober - Desember), Periode II yaitu pada puncak musim hujan (Januari-Maret), Periode awal musim kemarau (April -Juni) dan Periode IV puncak musim kemarau (JuliSeptember).

6. Merujuk poin 5 di atas, maka akan diperoleh nilai masing - masing dari Model Flow Persistance untuk tiap-tiap periode yang menggambarkan kondisi aliran sungai.

\section{HASIL DAN PEMBAHASAN}

\section{Analisis Laju Perubahan Lahan}

Bersumber dari peta yang telah disusun oleh Balai Pengelolaan- Daerah Aliran Sungai dan HutanLindung (BP- DASHL) Indragiri Rokan,bahwa DAS Siak 
bagian hulu memiliki luas kurang lebih 195.947,19 ha. Masih bersumber dari peta yang telah disusun oleh BP DASHL Indragiri Rokan bahwa jenis penggunaan lahan pada DAS Siak bagian hulu meliputi lahan perkebunan, hutan lahan kering sekunder, hutan rawa sekunder, pertanian lahan kering campur semak, semak belukar, lahan terbuka dan lahan lainnya.

Selanjutnya deskripsi pola penggunaan lahan pada DAS Siak bagian hulu dari tahun 1990 sampai tahun 2003 atau kurang lebih selama kurun waktu 13 tahuntelah terjadi perubahan penggunaan tata guna lahan yang cukup signifikan khususnya hutan lahan kering sekunder, hutan rawa sekunder, perkebunan dan pertanian lahan kering campur semak. Sebagai ilustrasi perubahan penggunaan lahan seperti yang didiskripsikan di atas dengan merujuk pada peta penggunaan lahan tahun 1990 dan peta penggunaan lahan tahun 2003 di DAS Siak bagian hulu seperti yang disajikan pada Gambar 2 dan Gambar 3 sebagai berikut:

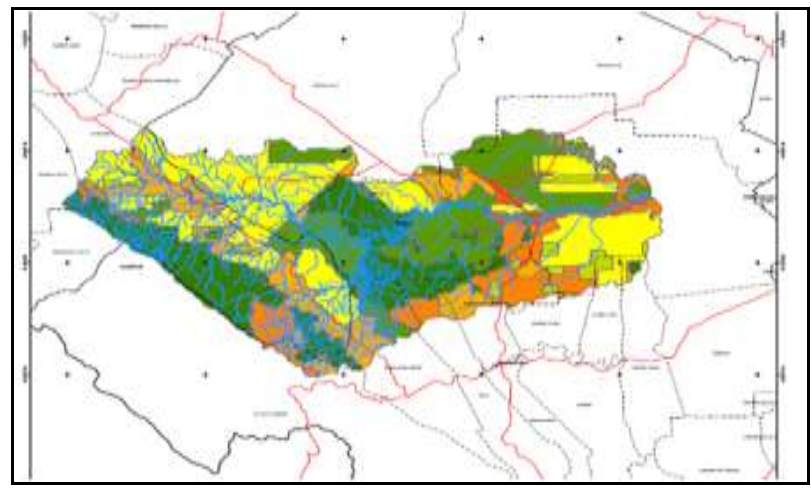

Gambar 2 Tata Guna Lahan Tahun 1990 Sumber : BP-DASHL Indragiri Rokan

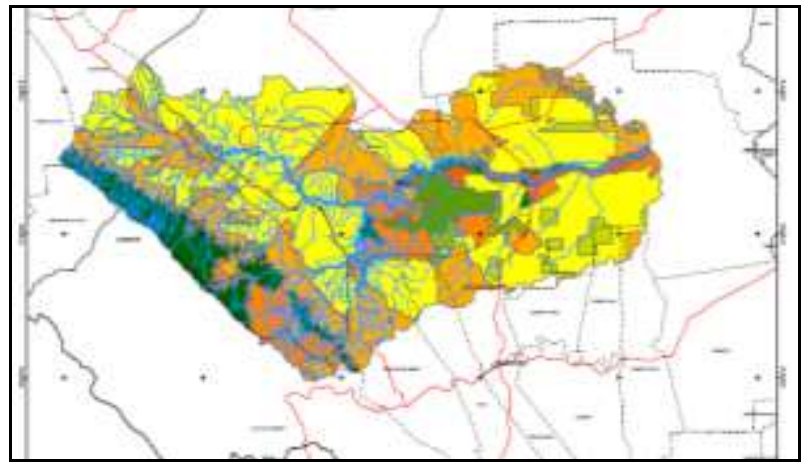

Gambar 2 Tata Guna Lahan Tahun 1990 Sumber : BP-DASHL Indragiri Rokan
Selanjutnya penggunaan lahan pada DAS Siak bagian hulu yang meliputi lahan perkebunan, hutan lahan kering sekunder, hutan rawa sekunder, pertanian lahan kering campur semak, semak belukar, lahan terbuka dan lahan lainnya, yang secara spesifik ditandai laju perubahan hutan lahan kering sekunder dan hutan rawa sekunder yang cukup signifikan, sejak tahun 1990 sampai tahun 2006 terjadi fenomena pengurangan luas lahan total dari hutan lahan kering sekunder dan hutan rawa sekunder dari tahun 1990 seluas 82.972,08 ha menjadi 12.042,31 ha pada saat tahun 2006 atau terjadi pengurangan seluas $64.779,05$ ha yang setara kurang lebih $85.5 \%$ selama kurun waktu 16 tahun. Selanjutnya masih selama kurun waktu dari tahun 1990 sampai dengan tahun 2006 terjadi perubahan luasan khususnya untuk perkebunan dan pertanian lahan kering campur semak.

Di sisi lain sejak tahun 1990 sampai dengan tahun 2006 terjadi fenomena penambahan penggunaan luas lahan untuk Perkebunan dari tahun 1990 sebesar $57.254,57$ ha menjadi $88.030,84$ ha pada saat tahun 2006 atau terjadi penambahan luasan sebesar $53.75 \%$, sedangkan untuk Pertanian lahan kering campur semak dari tahun 1990 sebesar $26.426,29$ ha menjadi 50874,56 ha pada saat tahun 2006 atau terjadi penambahan sebesar 34.842 ha atau setara dengan $92.51 \%$.

Berikut adalah data curah hujan yang disajikan dalam bentuk grafik seperti pada Gambar 4 di bawah ini.

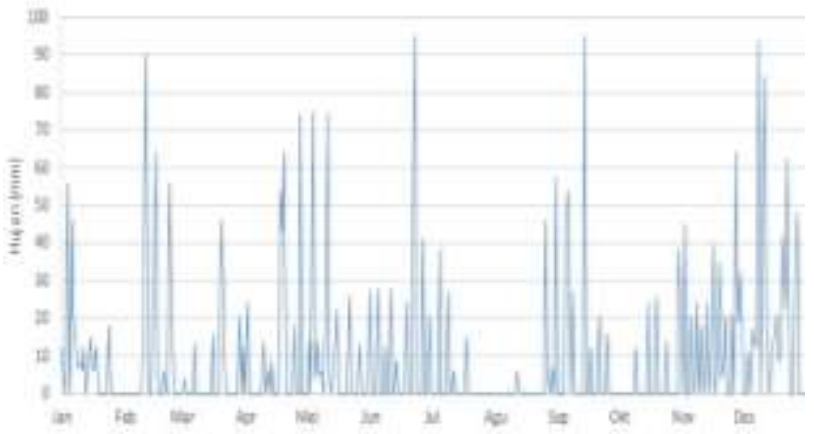

Gambar 4. Grafik Hubungan Data Curah Hujan Harian sebagai Fungsi Waktu untuk Tahun 2006

Sumber : BWS Sumatera III

langkah kedua adalah data debit yang bersumber dari hasil pencatatan Stasiun Automatic Water Level Record (AWLR) Pantai Cermin yang mendiskripsikan pola hubungan antara fluktuasi tinggi muka air sungai terhadap fungsi waktu atau yang lazim disebut stage hydrograph yang selanjutnya dilakukan proses transformasi dari 
stage hydrograph menjadi discharge hydrograph dengan bantuan persamaan rating curve yang telah disusun oleh BWS III Sumatera yang selengkapnya menggunakan grafik data debit harian sebagai fungsi waktu tahun 2006 seperti yang disajikan pada Gambar 5 di bawah ini.

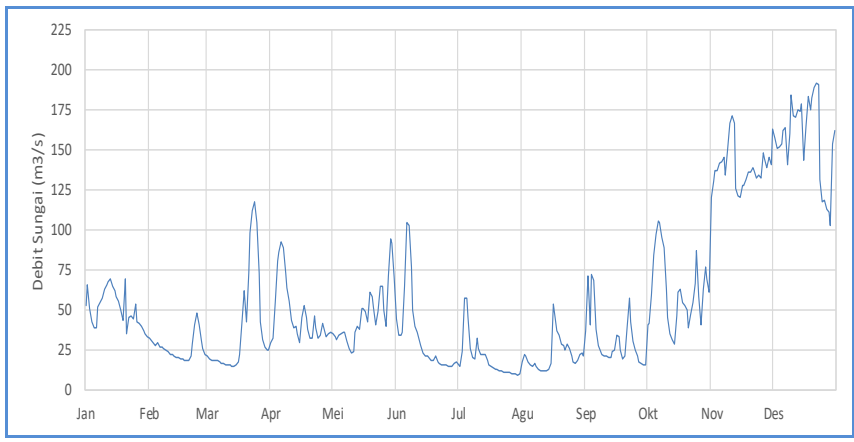

Gambar 5 Grafik data Debit Harian Sebagai

Fungsi Waktu Tahun 2006

Sumber: BWS Sumatera III

Selanjutnya, setelah debit dihitung lalu mengurutkan debit dalam setahun dari bulan januari sampai desember dan tentukan nilai debit maksimum dan debit minimum dalam setahun.

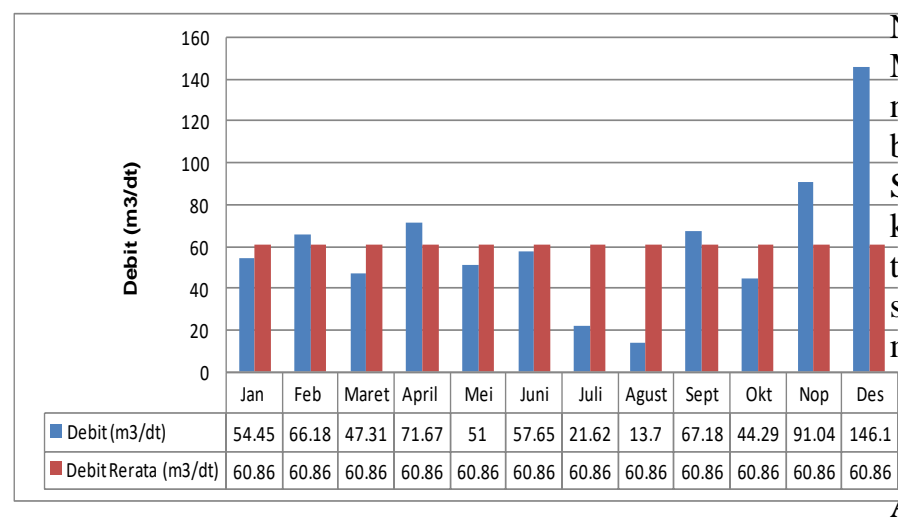

Gambar 4.16 Hubungan antara nilai Debit Bulanan Dan Debit Rerata Pada Tahun 2006

Sumber : Hasil Perhitungan

Selanjutnya masih bersumber dari Gambar 4.16 di atas , maka diperoleh nilai debit maksimum (Qmaks) yang terjadi pada bulan Desember tahun 2006 sebesar 146.1 $\mathrm{m}^{3} / \mathrm{dt}$ serta nilai debit minimum (Qminimum) yang terjadi pada bulan Agustus tahun 2006 sebesar 13.7 $\mathrm{m}^{3} / \mathrm{dt}$ sehingga akan diperoleh nilai KRA tahun 2006 adalah sebagai berikut :

$$
K R A=\frac{146.1}{13.7}=10.7
$$

Untuk nilai KRA sebesar 10.7, dengan merujuk dari Permenhut RI No. P.61/ Menhut-II/2014 memiliki kriteria kelas sedang dengan rentang nilai $10<$ KRA $<15$. Untuk selanjutnya hasil perhitungan KRA dari tahun 2006 sampai tahun 2016 selengkapnya disajikan seperti pada Tabel 4.4 di bawah ini.

Tabel 4.4 Nilai Koefisien Rezim Aliran (KRA) Tahun $2006-2016$

\begin{tabular}{lllll}
\hline Tahun & $\begin{array}{c}\text { Q maks } \\
(\mathbf{m 3} / \mathbf{d t})\end{array}$ & $\begin{array}{c}\text { Qmin } \\
(\mathbf{m 3 / d t})\end{array}$ & $\begin{array}{l}\text { Q maks/ } \\
\text { Qmin } \\
(\mathbf{n o n} \\
\mathbf{d i m e n s i})\end{array}$ & Klasifikasi \\
\hline 2006 & 146.19 & 13.7 & 10.67 & Sedang \\
2007 & 110.68 & 29.61 & 3.74 & Sangat Baik \\
2008 & 141.97 & 16.22 & 8.73 & Baik \\
2009 & 168.95 & 20.52 & 8.23 & Baik \\
2010 & 128.65 & 30.63 & 4.20 & Sangat Baik \\
2011 & 132.06 & 16.00 & 8.253 & Baik \\
2012 & 142.97 & 33.99 & 4,21 & Sangat baik \\
2013 & 135.77 & 14.96 & 9.075 & Baik \\
2014 & 157.59 & 19.43 & 8.11 & Baik \\
2015 & 102.39 & 11.13 & 9.199 & Baik \\
2016 & 107.71 & 7.7 & 13.99 & Sedang \\
\hline
\end{tabular}

Sumber : Hasil Analisis berdasarkan Permenhut No.61/2014

Merujuk Tabel 4.4 di atas, mengindikasikan bahwa nilai KRA yang menunjukkan nilai rasio antara besaran debit pada musim penghujan dan debit Sungai Siak pada musim kemarau memiliki kecenderungan klasifikasi tingkat baik dari tahun 2006 - 2016 kecuali tahun 2006 dan tahun 2016 memiliki klasifikasi tingkat sedang bahkan tahun 2007, tahun 2010 dan tahun 2012 memiliki klasifikasi tingkat sangat baik.

\section{DAFTAR PUSTAKA}

Asdak, C., 2010. Hidrologi dan Pengelolaan Daerah Aliran Sungai. Gadjah Mada University Press, Yogyakarta

2015. Laporan Akhir Rencana Umum Pengelolaan DAS Kampar Pusat Pengendalian Pembangunan Ekoregion Sumatera (P3ES) Kementerian Lingkungan Hidup dan Kehutanan (LHK) Republik Indonesia.

2014. Peraturan Menteri Kehutanan No.61/Menhut II/ 2014 Tentang Monitoring dan Evaluasi Daerah Aliran Sungai (DAS), Kementerian Lingkungan Hidup dan Kehutanan (LHK) Republik Indonesia. 